\title{
Study of Different Nitrogen Levels on Growth, Yield and Economics of Rice Variety BPT 2270- Bavapurisannalu under Low Land Condition
}

\author{
K. Anny Mrudhula*, B. Krishna Veni and Y. Suneetha \\ Agricultural Research Station, Bapatla, India \\ *Corresponding author
}

\section{A B S T R A C T}

\begin{tabular}{|c|}
\hline Keywords \\
\hline $\begin{array}{l}\text { Rice variety BPT } \\
2270 \\
\text { Bavapurisannalu, } \\
\text { Nitrogen Levels }\end{array}$ \\
\hline Article Info \\
\hline $\begin{array}{l}\text { Accepted: } \\
20 \text { August } 2020 \\
\text { Available Online: } \\
\text { 10 September } 2020\end{array}$ \\
\hline
\end{tabular}

The experiment was conducted at Agricultural Research Station, Bapatlain kharif2014 and 2015 to find out the effect of nitrogen levels on yield components and yield of BPT 2270 Bavapurisannalu. The experiment was laid out in a randomized block design with 7 treatments replicated thrice. Seven levels of nitrogen $(80,120,160,200,240,280$ and 320 $\mathrm{kg} \mathrm{N} \mathrm{ha}{ }^{-1}$ ) were used as an experimental treatments. Results revealed that nitrogen had significant positive effect in terms of tillers hill ${ }^{-1}$, grains panicle ${ }^{-1}$ grain yield, straw yield and economics. The results revealed that application of $320 \mathrm{~kg} \mathrm{~N}^{-1}$ recorded significantly the highest yield attributing characters like productive tillers plant ${ }^{-1}$, panicle length, number of filled grains per panicle and grain yield (5496 and $5738 \mathrm{~kg} \mathrm{ha}^{-1}$ ) while lowest yield was recorded with $80 \mathrm{~kg} \mathrm{~N}^{-1}$ treatment. Highest net returns and benefit cost ratio was recorded with $240 \mathrm{~kg} \mathrm{~N}^{-1}$ haring 2014 and 2015. It can be indicated that application of $240 \mathrm{~kg} \mathrm{~N} \mathrm{ha}^{-1}$ is more economical to the BPT 2270 long duration variety in both the years of experimentation.

\section{Introduction}

Rice is the most important food crop, grown in the tropics. It accounts for the bulk of the caloric intake of the people in Asia and for a considerable portion of the diets in tropical Africa and Asia. The present strategy of increasing food production essential involved the balance use of fertilizers to rice, because all the varieties of rice give their fully yield potential with adequate supply of nutrients. Various factors contributing for rice production, fertilizers play an important role.Among the major plant nutrients, nitrogen is most important for augmenting rice yield. Rice is the major consumer of fertilizer nitrogen and accounts for one third of the total nitrogen consumption in the country. Nitrogen is essential nutrient element for rice growth and metabolic process (Noor, 2017). Application of optimum dose of nitrogen to rice is gaining importance because nitrogen is a key nutrient in crop production that it can never be ignored. Use of adequate nitrogen rate is important not only for obtaining maximum economic returns, but also to reduce environmental pollution. Nitrogen management in rice field is different from other crops because of the continuous submergence of the field. Nitrogen $(\mathrm{N})$ is the 
indispensable nutrient to rice production and its uptakes is affected by rice varieties, environment, soil conditions, crop rotations etc. Managing nitrogen fertilization in rice fields is a challenging task for farmers because of various kinds of losses due to denitrification, deep percolation and run-off in flooded soils resulting in low nitrogen use efficiency. Consequently environment of root zone is converted from aerobic to an aerobic condition. During these processes losses of nitrogen takes place through leaching and denitrification in leaching losses, unhydrolyzed nitrogen is as susceptible to leaching as nitrogen in denitrification process, after converting nitrogen in to nitrate which is soluble in water and therefore, move down to reduced layer, where it is denitrified. These types of losses are responsible forits lower efficiency. Excessive nitrogen application can result in accumulation of large amounts of post-harvest residual soil nitrogen. Residual soil nitrate (NO-3) may be available for subsequent crops in the next season, but such nitrogen is highly susceptible to leaching during non-crop periods. It is important to achieve efficient use of nitrogen in chemical fertilizers, not only through cultivation techniques, but also by breeding varieties with high nitrogen use efficiency and reducing nitrogen inputs from farming to the environment (Sachiko et al., 2009).The present investigation was to assess variability in yield components, yield and economics of rice variety under different nitrogen levels.

\section{Materials and Methods}

Field experiment was carried out for two consecutive seasons of kharif, 2014 and 2015 at Agricultural Research Station, Bapatla. The soil is clay loam in texture. The soil is neutral ( $\mathrm{pH}$ 7.49) in reaction with low electrical conductivity $\left(0.24 \mathrm{dSm}^{-1}\right)$. The soil is medium in organic carbon content, low in available nitrogen, medium in available phosphorus and potash. The experiment was laid out in randomized block design with 7 treatments replicated thrice. Seven nitrogen levels (80, 120, 160, 200, 240,280 and $320 \mathrm{~kg} \mathrm{~N}^{-1}$ ) were used as an experimental treatments. Rice variety BPT 2270- Bavapurisannalu was sown separately in nurseryand 25 days old seedlings were transplanted at $20 \mathrm{~cm} \mathrm{x} 15 \mathrm{~cm}$ spacing@two seedlings per hill in both the years. Nitrogen (Urea) was applied as per treatments in three equal splits $(1 / 3$ as basal, $1 / 3$ at maximum tillering and $1 / 3$ at panicle initiation stage). Phosphorus (60 kg ha ${ }^{-1}$ ) and potassium $\left(40 \mathrm{~kg} \mathrm{ha}^{-1}\right)$ were supplied through single super phosphate and muriate of potash and were uniformly applied to all plots as basal during kharif2014 and 2015. Irrigation and weed management was done in time to time. The plant height was measured from ground level to the apex of last fully opened leaf during vegetative period and upto the tip of the panicle after flowering. Panicle length of ten randomly selected panicles from each plot was measured from neck node to the tip of panicle and then averaged and expressed in $\mathrm{cm}$. Number of grains of 10 randomly selected panicles from each plot were counted and then averaged as grains panicle ${ }^{-1}$. Samples of grain collected separately at the time of threshing from each plot were dried properly. 1000-grains from each of these samples were taken and their weights were recorded and expressed in grams. The border rows were harvested first and then, the net plot area was harvested and the produce was threshed by beating on a threshing bench, cleaned and sun dried to 14 per cent moisture level. Grain from net plot area was thoroughly sun dried, threshed, cleaned and weight of grains was recorded and expressed in yield per hectare. The data were analyzed statistically following the method given by Panse and Sukhatme (1978) and wherever the results were calculated at 5 per cent level of significance. 


\section{Results and Discussion}

\section{Effect of Nitrogen Levels on growth}

At maturity, significantly the tallest plant was recorded with $320 \mathrm{~kg} \mathrm{~N}^{-1}(98.9$ and 102.7 $\mathrm{cm})$ and it was on par 280, 240, 200 and 160 $\mathrm{kg} \mathrm{N}$ ha $^{-1}$ when compared to 120 and $80 \mathrm{~kg} \mathrm{~N}$ $\mathrm{ha}^{-1}$ and the lowest plant height was recorded with $80 \mathrm{~kg} \mathrm{~N} \mathrm{ha}^{-1}$ (88.7 and $93.9 \mathrm{~cm}$ ) during both the years. Nitrogen is associated with increase in protoplasm, cell division and cell enlargement resulting in taller plants
(Chamely et al., 2015), and also in increased chlorophyll content at all growth stages, might have increased the photosynthesis and resulted in increased plant height (Rusdiansyah and Muhammad saleh, 2017).Similarly, higher number of tillers was observed at higher levels of nitrogen.During both the years of study significantly maximum number of productive tillers/plant were recorded with the application of $240 \mathrm{~kg}$ $\mathrm{Nha}^{-1}(13$ and 13) where as the lowest number of tillers per plant was recorded with $80 \mathrm{~kg} \mathrm{~N}$ $\mathrm{ha}^{-1}$ (10 and 10) treatment (Table 1).

Table.1 Effect of nitrogen levels on growth of BPT 2270

\begin{tabular}{|l|c|c|c|c|}
\hline \multirow{2}{*}{ Treatment } & \multicolumn{3}{|c|}{ Plant height (cm) } & \multicolumn{2}{c|}{ No of tillers/plant } \\
\cline { 2 - 5 } & $\mathbf{2 0 1 4}$ & $\mathbf{2 0 1 5}$ & $\mathbf{2 0 1 4}$ & $\mathbf{2 0 1 5}$ \\
\hline T1-80 kg N/ha & 88.7 & 93.9 & 10 & 10 \\
\hline T2- 120 kg N/ha & 90.5 & 98.2 & 10 & 11 \\
\hline T3- 160 kg N/ha & 92.2 & 98.7 & 11 & 11 \\
\hline T4- 200 kg N/ha & 94.7 & 98.9 & 12 & 12 \\
\hline T5-240 kg N/ha & 96.6 & 99.6 & 13 & 13 \\
\hline T6-280 kg N/ha & 98.3 & 100.9 & 12 & 12 \\
\hline T7-320 kg N/ha & 98.9 & 102.7 & 12 & 12 \\
\hline SEm & 2.4 & 2.3 & 0.3 & 0.4 \\
\hline CD $(\mathbf{0 . 0 5})$ & 7.4 & 7.1 & 1.0 & 1.0 \\
\hline CV $(\mathbf{\%})$ & 5.2 & 6.4 & 7.3 & 6.8 \\
\hline
\end{tabular}

Table.2 Effect of nitrogen levels on yield attributes of BPT 2270

\begin{tabular}{|l|c|c|c|c|c|c|}
\hline Treatment & \multicolumn{2}{|c|}{ Panicle length (cm) } & \multicolumn{2}{c|}{ No of grains/panicle } & \multicolumn{2}{c|}{ Test weight $\mathbf{( g )}$} \\
\hline & $\mathbf{2 0 1 4}$ & $\mathbf{2 0 1 5}$ & $\mathbf{2 0 1 4}$ & $\mathbf{2 0 1 5}$ & $\mathbf{2 0 1 4}$ & $\mathbf{2 0 1 5}$ \\
\hline T1-80 kg N/ha & 21.4 & 22.0 & 145 & 144 & 13.5 & 13.8 \\
\hline T2- 120 kg N/ha & 21.6 & 22.2 & 155 & 150 & 14.1 & 14.0 \\
\hline T3- 160 kg N/ha & 21.8 & 23.4 & 168 & 152 & 14.5 & 14.6 \\
\hline T4- 200 kg N/ha & 22.5 & 23.7 & 172 & 163 & 14.6 & 14.5 \\
\hline T5-240 kg N/ha & 23.0 & 24.9 & 180 & 184 & 14.8 & 15.2 \\
\hline T6-280 kg N/ha & 22.8 & 24.6 & 174 & 180 & 14.8 & 14.8 \\
\hline T7-320 kg N/ha & 22.9 & 24.8 & 175 & 170 & 14.8 & 14.5 \\
\hline SEm \pm & 0.3 & 0.5 & 3.7 & 4.6 & 0.2 & 0.2 \\
\hline CD $(\mathbf{0 . 0 5}$ & 1.0 & 1.2 & 11.0 & 13.9 & 0.6 & 0.6 \\
\hline CV $(\%)$ & 5.0 & 5.5 & 6.5 & 7.2 & 4.1 & 4.4 \\
\hline
\end{tabular}


Table.3 Effect of nitrogen levels on grain yield, straw yield and harvest index of BPT 2270

\begin{tabular}{|l|c|c|c|c|c|c|}
\hline \multirow{2}{*}{ Treatment } & \multicolumn{2}{|c|}{ Grain yield (kg/ha) } & \multicolumn{2}{|c|}{ Straw yield (kg/ha) } & \multicolumn{2}{c|}{ Harvest index (\%) } \\
\cline { 2 - 7 } & $\mathbf{2 0 1 4}$ & $\mathbf{2 0 1 5}$ & $\mathbf{2 0 1 4}$ & $\mathbf{2 0 1 5}$ & $\mathbf{2 0 1 4}$ & $\mathbf{2 0 1 5}$ \\
\hline T1-80 kg N/ha & 4240 & 4631 & 5380 & 5735 & 42.5 & 43.5 \\
\hline T2- 120 kg N/ha & 4630 & 5081 & 5970 & 6260 & 42.7 & 43.8 \\
\hline T3- 160 kg N/ha & 4875 & 5125 & 6125 & 6375 & 43.0 & 44.0 \\
\hline T4- 200 kg N/ha & 5045 & 5200 & 6445 & 6455 & 43.2 & 44.2 \\
\hline T5-240 kg N/ha & 5435 & 5675 & 6895 & 6970 & 44.1 & 44.9 \\
\hline T6-280 kg N/ha & 5475 & 5625 & 7120 & 6795 & 43.5 & 44.3 \\
\hline T7-320 kg N/ha & 5496 & 5738 & 7340 & 6825 & 43.8 & 44.7 \\
\hline SEm & 127 & 122 & 145 & 152 & 0.2 & 0.2 \\
\hline CD (0.05) & 386 & 378 & 441 & 459 & 0.7 & 0.6 \\
\hline CV (\%) & 5.2 & 7.3 & 5.6 & 6.2 & 5.1 & 5.5 \\
\hline
\end{tabular}

Table.4 Effect of nitrogen levels on economics of BPT 2270

\begin{tabular}{|l|c|c|c|c|c|c|}
\hline \multirow{2}{*}{ Treatment } & \multicolumn{2}{|c|}{ Gross returns } & \multicolumn{2}{c|}{ Net returns } & \multicolumn{2}{c|}{ B:C Ratio } \\
\cline { 2 - 7 } & $\mathbf{2 0 1 4}$ & $\mathbf{2 0 1 5}$ & $\mathbf{2 0 1 4}$ & $\mathbf{2 0 1 5}$ & $\mathbf{2 0 1 4}$ & $\mathbf{2 0 1 5}$ \\
\hline T1-80 kg N/ha & 66860 & 72884 & -9096 & -3071 & 0.88 & 0.96 \\
\hline T2- 120 kg N/ha & 73105 & 79934 & -3344 & 3485 & 0.96 & 1.05 \\
\hline T3- 160 kg N/ha & 76812 & 80687 & -137 & 3738 & 1.00 & 1.05 \\
\hline T4- 200 kg N/ha & 79597 & 81855 & 2154 & 4412 & 1.03 & 1.06 \\
\hline T5-240 kg N/ha & 85702 & 89257 & 8765 & 11320 & 1.13 & 1.15 \\
\hline T6-280 kg N/ha & 86507 & 88357 & 8076 & 9926 & 1.10 & 1.13 \\
\hline T7-320 kg N/ha & 87032 & 90026 & 8106 & 11100 & 1.10 & 1.14 \\
\hline
\end{tabular}

\section{Effect of Nitrogen Levels on yield attributes}

Pooled data of two years on yield attributes were significantly superior over lowest level of nitrogen. Rice plants produced longest panicles $(23$ and $24.9 \mathrm{~cm}$ ) where $240 \mathrm{~kg}$ nitrogen per hectare was applied which remained statistically at par with that obtained by nitrogen application levels between 200 to $320 \mathrm{~kg}$ per hectare. The longer panicles obtained in treatments receiving higher nitrogen rates were probably due to better nitrogen status of plant during panicle growth period. The lowest shortest panicles (21.4 and $22.0 \mathrm{~cm}$ ) were recorded in $\mathrm{T}_{1}$ treatmenti.e 80 $\mathrm{kg} \mathrm{N} \mathrm{ha}{ }^{-1}$. Numbers of grains per panicle were more (180 and 184) at a nitrogen level of 240 $\mathrm{kgha}^{-1}$ which remained statistically at par with that obtained by nitrogen application levels between 200 to $320 \mathrm{~kg}$ per hectare. The lowest value of this parameter (145 and 144) was recorded in $\mathrm{T}_{1}$ treatment. Maximum number of total grains panicle ${ }^{-1}$ with the application of inorganic fertilizers might be due to better nutrition especially quick and adequacy of nitrogen probably favoured the cellular activities during panicle formation and development that might have led to increased number of grains panicle ${ }^{-1}$ (Tayefe al., 2014). Significantly maximum grain weight (14.8 and $15.2 \mathrm{~g}$ ) obtained in treatment where $240 \mathrm{~kg} / \mathrm{ha}$ nitrogen used. This might be due to increased translocation of more carbohydrates from source to sink, hence better filling of grains and bold seeds were 
obtained. These results are in conformity with the findings of Riteshsharma (2014) and Parimal panda et al., (2017) (Table 2).

\section{Effect of Nitrogen Levels on yield}

Graded levels of nitrogen had marked effect on grain yield, straw yield and harvest index. Grain and straw yield increased with increase in $\mathrm{N}$ levels, however significantly highest grain yield (5496 and $5738 \mathrm{~kg} \mathrm{ha}^{-1}$ ) was recorded with $320 \mathrm{~kg} \mathrm{~N}^{-1}$ when compared to $200,160,120$ and $80 \mathrm{~kg} \mathrm{~N}^{-1}$ and it was statistically at par with 280 and $240 \mathrm{~kg} \mathrm{~N} \mathrm{ha}^{-1}$ applied treatments during both the years of study. Straw yield also fallowed the same trend. Highest yield with higher nitrogen level might be due to better $\mathrm{N}$ uptake leading to greater dry matter accumulation and its translocation to their sink (Rajesh et al., 2015). The improvement in panicle length, panicle/ $\mathrm{m}^{2}$ and panicle weight was mainly responsible for higher yield with supply of nitrogen (Haque and Haque, 2016). Rice straw yield found to increase with increasing rate of nitrogen application significantly up to $320 \mathrm{~kg} \mathrm{~N} \mathrm{ha}^{-1}$ (7340 and $6825 \mathrm{~kg} \mathrm{ha}^{-1}$ ) and the lowest straw yield was recorded with $80 \mathrm{~kg} \mathrm{~N}$ ha $^{-1}\left(5380\right.$ and5735 kg ha $\left.{ }^{-1}\right)$ in 2014 and 2015. Significantly the highest harvest index of 44.1 $\%$ and $44.9 \%$ was recorded with $240 \mathrm{~kg} \mathrm{~N}$ ha ${ }^{1}$ when compared to $\mathrm{T} 1, \mathrm{~T} 2$ and $\mathrm{T} 3$ treatments and the lowest harvest index was recorded with $80 \mathrm{~kg} \mathrm{~N} \mathrm{ha}^{-1}$ applied treatment(42.5 and $43.5 \%$ ) in 2014 and 2015 but it was on a par with all other treatments (Table 3).

The increase in harvest index with increasing levels of nitrogen might be due to better translocation of assimilates from source to sink as was observed with number of filled grains per panicle and 1000 grain weight. These similar results are in conformity with the findings of Koffi Djaman et al., (2016) and Djaman et al., (2018).

\section{Effect of nitrogen levels on economics}

Gross returns, net returns and benefit cost ratio were worked out for different nitrogen levels for BPT 2270-Bavapuri sannalu variety. The data on economics presented in Table-4. Among the nitrogen levels $320 \mathrm{~kg} \mathrm{~N}$ $\mathrm{ha}^{-1}$ recorded maximum gross returns $(87,032$ and 90,026 Rs. ha ${ }^{-1}$ ) and $240 \mathrm{~kg} \mathrm{~N} \mathrm{ha}{ }^{-1}$ recorded highest net returns $(8,765$ and 11,320 Rs. ha ${ }^{-1}$ ) and benefit cost ratio (1.3and 1.5) during both the years of study. These results are in agreement with the findings of Dushyant Mishra et al., (2015) and Kuldeep Dangi et al., (2017).

In conclusions the application of different levels of nitrogen is one of important factor to increase the growth and yield of rice varieties. The results of this study indicated that the increased nitrogen levels up to $320 \mathrm{~kg} \mathrm{~N}^{-1}$ significantly enhanced the grain yield and the yield components. Thus, it is concluded that for achieving maximum yield and net return rice variety BPT 2270-Bhavapuri sannalu fertilized with240 $\mathrm{kg} \mathrm{ha}^{-1}$ may be adopted under irrigated condition of Krishna Western delta. The results are to be confirmed further for making the recommendation.

\section{References}

Chamely, S.G., Islam, N.,Hoshain, S., Rabbani, M.G., Kader, M.A and Salam M.A. 2015.Effect of variety and nitrogen rate on the yield performance of bororice. Progressive Agriculture. 26 (1): 6-14.

Djaman, K., Mel, V.C., Ametonou, F.Y., ElNamaky, R., Diallo, M.D and Koudahe, K. 2018.Effect of Nitrogen Fertilizer Dose and Application Timing on Yield and Nitrogen Use Efficiency of Irrigated Hybrid Rice under Semi-Arid Conditions. Journal of Agricultural Science and Food Research.9:2.

Dushyant Mishra, J., Sharma, D., Asheesh Kumar Pandey, Rajeeva Kumar Mishra, U.N. Shukla and Jitendra Kumar. Effect of 
nitrogen levels on yield, quality and economics of rice (Oryza sativa) varieties. International journal of Agricultural statistics and Science.Vol. 11(1) ISSN: 0973-1903

Haque, M. A and Haque, M. M. 2016. Growth, yield and nitrogen use efficiency of new rice variety under variable nitrogen rates. American Journal of Plant Sciences. 7:612-622.

KoffiDjaman., Boubie, V., Bado, Valere, C and Mel.2016. Effect of nitrogen fertilizer on yield and nitrogen use efficiency of four aromatic rice varieties Emirates Journal of Food and Agriculture. 28(2): 126-135.

KuldeepDangi, S.K., Singh, D.K., Malviya, A.,Gautam, N.,Kanapuriya and Balvendra Kumar. 2017. Effect of Rice Varieties on Growth, Yield and Economics at Varying Levels of Nitrogen under Direct Seeded Upland Condition Rewa Region. International Journal of Current Microbiology and Applied Sciences.6(9): 2313-2318.

Noor, M.A. 2017. Nitrogen management and regulation for optimum NUE in maize-A mini review, Soil Crop Sci., https://www.cogentoa.com/article/10.1080/ 23311932.1348214

Panse, V.G and Sukhatme, P.V.1978. Statistical methods for Agricultural workers. ICAR, New Delhi.199-211.

Parimal Panda, ParthaSarathiPatra, Ranajit Panda, Arindam Kundu, A.K., Singha Roy and Nabakishor Mahato. 2017. Effect of Different levels of Nitrogen on Growth and Yield of Rice (Oryza sativa L.) Cultivars under Terai-agro Climatic
Situation. International Journal of Current Microbiology and Applied Sciences. 6(9): 2408-2418.

Rajesh, K., Padma, V., Voleti, S.R., Radhika, K and Siva Sankar, A. 2015. Response of rice (Oryzasativa) varieties on nitrogen use efficiency and yield under different nitrogen levels. Annals of Plant and Soil Research. 17 (Special Issue): 161-163.

Ritesh Sharma, Raveesh Kumar gangwar, Vivek Yadav and Rakesh Kumar. 2014. Response of Basmati rice (Oryza sativa) cultivars to graded nitrogen levels under transplanted condition.I nternational Journal of Research in Applied Natural and Social Sciences.I SSN(E): 2321-8851; Vol. 2(9): 330-384.

Rusdiansyah and Muhammad Saleh. 2017. Response of Two Local Rice Cultivars to Different Doses of Nitrogen Fertilizer in Two Paddy Fields. Journal of Agricultural Science. 39(2): 137-144.

Sachiko, N., Kazunobu, T., Yoshimichi, F.2009.Genetic variations in dry matter production and physiological nitrogen use efficiency in rice (Oryza sativa L.) varieties. Breeding Science. 59: 269-276

Tabar, Y. 2012. Effect of nitrogen and phosphorus fertilizer on growth and yield rice (Oryza sativaL.). International journal of Agronomy and Plant Production. 3(12):579-584.

Tayefe, M., Gerayzade, A., Amiri, E andZade, A. N. 2014.Effect of nitrogen on rice yield, yield components and quality parameters. African Journal of Biotechnilogy. 13(1): 91-105.

\section{How to cite this article:}

Anny Mrudhula, K., B. Krishna Veni and Suneetha, Y. 2020. Study of Different Nitrogen Levels on Growth, Yield and Economics of Rice Variety BPT 2270- Bavapurisannalu under Low Land Condition. Int.J.Curr.Microbiol.App.Sci. 9(09): 3126-3131. doi: https://doi.org/10.20546/ijcmas.2020.909.385 